\title{
ANALISIS EFISIENSI PENGENDALIAN BIAYA KUALITAS PADA \\ AKSAN BAKERY MANADO
}

\author{
Fitriayani Adam \\ Hendrik Manossoh \\ Sherly Pinatik \\ Fakultas Ekonomi dan Bisnis, Jurusan Akuntansi \\ Universitas Sam Ratulangi Manado \\ Email : fitriayani.adam@yahoo.com
}

\begin{abstract}
Quality being the competitiveness of the most important for the company's products and also because the quality has been the hope and desire of everyone, especially the consumer. Customers are not going to focus on a product / service only in terms of price but in good quality inherent in the product or service. Viewed from the importance of the quality of products, each company needs to spend quality, cost of quality is the cost refers to the cost incurred to prevent or expenses incurred as a result of producing a quality product. Efforts to improve the quality of the product will not run without the cost of quality control to overcome the problems faced by the company, where quality control can help the company determine the feasibility of the quality of products based on control limits have been set. This study aims to see how the cost of quality control and to analyze the efficiency of the implementation cost of quality control conducted by Aksan Bakery in Manado. Analysis of the data used is descriptive analysis with qualitative approach and using methods of presentation quality cost ratio analysis to assess the efficiency cost of quality. Based on analysis of the cost of quality control conducted by the company it appears that the cost of quality control conducted by the company do not meet the quality standards that have been set at $2.5 \%$ of sales, for the cost of quality issued by the company is greater than a predetermined quality standards, namely amounting to 13.89\% of sales. This may imply that the cost of quality control has not been carried out efficiently.
\end{abstract}

Keywords : Efficiency, Cost of Quality

\section{Latar Belakang}

\section{PENDAHULUAN}

Seiring dengan membaiknya kondisi perekonomian Indonesia dan dimulainya era pasar bebas, perusahaan semakin dituntut untuk dapat mempertahankan bahkan meningkatkan keunggulan produk yang dimilikinya agar dapat bersaing dalam "pasar" dan menjalankan kegiatan operasi secara kontinyu di tengah persaingan yang semakin ketat. Salah satu cara yang dapat ditempuh adalah dengan meningkatkan kualitas produk yang dihasilkan. Kualitas bagi perusahaan adalah faktor kunci yang membawa keberhasilan bisnis, pertumbuhan dan peningkatan posisi bersaing. Suatu industri tidak akan eksis apabila produk yang dibuat tidak sesuai dengan keinginan konsumen (Buchori, M. Khuwarismi, 2012). Produk berkualitas adalah produk yang dapat memenuhi harapan konsumen. Beberapa definisi kualitas menekankan pada aspek yang berbeda-beda, misalnya kecocokan penggunaan, kesesuaian produk dengan kebutuhan konsumen, kesesuaian produk dengan spesifikasi desain dan persyaratan teknisnya.

Garrison (2013:79) menjelaskan bahwa produk yang memenuhi atau melebihi spesifikasi desain serta bebas dari cacat yang mungkin mempengaruhi penampilan atau mengurangi kinerjanya disebut sebagai produk yang memiliki kualitas kesesuaian (quality of conformance) yang tinggi. Kualitas menjadi daya saing yang paling penting bagi produk perusahaan dan juga karena kualitas telah menjadi harapan dan keinginan setiap orang khususnya konsumen. Manajer perlu memperhatikan masalah kualitas yang merupakan salah satu bagian penting dalam menjalankan strategi operasinya ditengah kompetisi dan persaingan dalam berbisnis. Melihat dari pentingnya kualitas produk maka setiap perusahaan perlu mengeluarkan biaya kualitas. 
Prawironegoro dan Purwanti (2013:19) mengemukakan bahwa biaya kualitas adalah biaya yang timbul karena produk yang dihasilkan mutunya jelek sehingga tidak disukai oleh konsumen. Ada empat kategori biaya kualitas menurut Garrison (2012:80-81) yaitu biaya pencegahan, biaya penilaian, biaya kegagalan internal, dan biaya kegagalan eksternal. Untuk menghasilkan kualitas terbaik diperlukan upaya perbaikan berkesinambungan terhadap kemampuan manusia, proses, dan lingkungan. Untuk itu dalam mengatasi masalah yang dihadapi oleh perusahaan, maka perusahaan perlu melakukan pengendalian terhadap biaya kualitas.

Pengendalian kualitas adalah aktifitas pengendalian proses untuk mengukur ciri-ciri kualitas produk, membandingkan dengan spesifikasi atau persyaratan, dan mengambil tindakan penyehatan yang sesuai apabila ada perbedaan antara penampilan yang sebenarnya dan yang standar. Yang mendasari terjadinya pengendalian terhadap biaya kualitas adalah kurangnya perhatian manajemen terhadap hal-hal yang bisa menyebabkan kerusakan produk. Suatu cara yang dapat dilakukan oleh perusahaan untuk pengendalian kualitas yaitu dengan mngidentifikasi biaya-biaya yang termasuk kedalam biaya kualitas dan disusun dalam laporan biaya kualitas yang disusun setiap periode.

Aksan Bakery adalah salah satu perusahaan manufaktur yang mengolah bahan mentah menjadi bahan jadi dengan hasil produksi yaitu roti. Dalam menjanlankan kegiatan produksinya perusahaan perlu memperhatikan mengenai tingkat kerusakan produk dan kualitas roti yang akan diproduksi. Untuk itu penulis tertarik untuk melakukan penelitian dengan mengambil judul analisis efisiensi pengendalian biaya kualitas.

\section{Tujuan Penelitian}

Tujuan penelitian ini adalah untuk menganalisis efisiensi pelaksanaan pengendalian biaya kualitas yang dilakukan pada Aksan Bakery.

\section{Akuntansi Biaya}

\section{TINJAUAN PUSTAKA}

Mulyadi (2012:7) akuntansi biaya adalah proses pencatatan, penggolongan, peringkasan dan penyajian biaya pembuatan dan penjualan produk atau jasa, dengan cara-cara tertentu serta penafsiran terhadapnya. Menurut Ahmad Dunia dan Wasilah Abdullah (2012:4) tujuan atau manfaat akuntansi biaya adalah menyajikan informasi yang berguna kepada pihak-pihak yang berkepentingan untuk pengambilan keputusan ekonomi.

\section{Pengertian Biaya}

Menurut Mulyadi (2012:3), Dalam arti luas biaya adalah pengorbanan sumber ekonomi yang diukur dalam satuan uang, yang telah terjadi atau mungkin terjadi untuk mencapai tujuan tertentu. Dalam arti sempit biaya merupakan bagian dari harga pokok yang dikorbankan dalam usaha untuk memperoleh penghasilan.

\section{Penggolongan Biaya}

Penggolongan biaya adalah proses mengelompokan secara sistematis atas keseluruhan elemen yang ada ke dalam golongan-golongan tertentu yang lebih ringkas untuk dapat memberikan informasi yang lebih penting. Kebutuhan informasi ini mendorong timbulnya berbagai cara penggolongan biaya sehingga dikenal dengan konsep penggolongan biaya yang berbeda sesuai dengan tujuan yang berbeda "different costs for different purpos"(Mulyadi, 2009:13).

\section{Pengertian Biaya Kualitas}

Krismiaji dan Aryani (2011:390) menyatakan bahwa biaya kualitas adalah biaya yang terjadi karena kualitas produk yang dihasilkan rendah. Jika penerapan biaya kualitas dalam suatu perusahaan sudah berjalan dengan baik maka semakin kecil kemungkinan dari kurangnya kualitas atau meminimalkan terjadinya kerusakan produk atau produk cacat. Kusumawati (2014) juga mengemukakan biaya kualitas adalah biaya-biaya yang timbul karena telah terdapat produk yang buruk kualitasnya atau pencegahan atas kualitas yang jelek dimasa yang akan dating.

\section{Penggolongan Biaya Kualitas}

Garrison (2012:?) mengungkapkan bahwa komponen biaya kualitas dapat diklasifikasikan ke dalam 4 kategori, yaitu: 
1. Biaya pencegahan (Prevention cost)

Biaya ini dikeluarkan untuk mendesain produk dan sistem produksi bermutu tinggi, termasuk biaya untuk menerapkan dan memelihara sistem-sistem tersebut.

2. Biaya penilaian (Appraisal cost)

Biaya penilaian adalah biaya yang terjadi untuk mendeteksi kegagalan produk. Biaya ini dikeluarkan dalam rangka pengukuran dan analisis data untuk menentukan apakah produk atau jasa sesuai dengan spesifikasinya.

3. Biaya kegagalan internal (Internal failure cost)

Biaya kegagalan internal adalah biaya yang dikeluarkan karena rendahnya kualitas yang ditemukan sejak penilaian awal sebelum mnyerahkan produk sampai kepada pelanggan.

4. Biaya kegagalan eksternal (Eksternal failure cost)

Biaya kegagalan eksternal yaitu biaya-biaya yang berhubungan dengan kesalahan dan nonkonformasi (errors and nonconformance) yang ditemukan setelah produk itu diserahkan ke pelanggan.

\section{Perilaku Biaya Kualitas}

Menurut para pakar kualitas, sebagaimana yang dikemukakan oleh Nasution (2001:132) bahwa, suatu perusahaan dengan program pengelolaan kualitas yang berjalan dengan baik, biaya kualitasnya tidak lebih besar dari 2,5\% dari penjualan.Perusahaan harus dapat mengidentifikasikan perilaku setiap elemen biaya kualitas secara individual untuk mencapai standar biaya kulitas yang telah ditetapkan. Sebagian biaya kualitas bervariasi dengan penjualan, namun sebagian lainnya tidak. Agar laporan kinerja kualitas dapat bermanfaat yang harus diperhatikan yaitu:

1. Biaya kualitas harus digolongkan ke dalam biaya variabel dan biaya tetap dihubungkan dengan penjualan.

2. Untuk biaya variabel, penyempurnaan kualitas dicerminkan oleh pengurangan rasio biaya variabel.

3. Untuk biaya tetap, penyempurnaan biaya kualitas dicerminkan oleh perubahan absolut jumlah biaya tetap.

\section{Pengertian Pengendalian Biaya Kualias}

Pengendalian pada prinsipnya dapat memperhatikan suatu kegiatan dan selalu mengawasi aktivitas sehari-hari, maka pengendalian biaya adalah proses atau usaha yang sistimatis dalam penetapan standar pelaksanaan dengan tujuan perencanaan, sistem informasi umpan balik, membandingkan pelaksanaan nyata dengan perencanaan menentukan dan mengatur penyimpanganpenyimpangan serta melakukan koreksi perbaikan sesuai dengan rencana yang telah ditetapkan, sehingga tujuan tercapai secara efektif dan efisien dalam penggunaan biaya. Fungsi pengendalian kualitas, bukan saja untuk memperoleh kualitas produk yang sesuai dengan standar, tetapi juga untuk mengetahui tingkat efisiensi. Pengendalian kualitas merupakan teknik yang sangat bermanfaat agar suatu perusahaan dapat mengetahui kualitas produknya sebelum dipasarkan kepada konsumen. Teknik pengendalian kualitas dapat membantu perusahaan dalam mengetahui kelayakan kualitas produk berdasarkan batas-batas kontrol yang telah ditentukan.

\section{Pengertian Efisiensi}

Fahmi (2012:83) menyebutkan efisiensi adalah pengukuran kinerja yang melihat dari segi pengerjaan sesuai dengan waktu (time) yang direncanakan, bahkan akan lebih baik jika bisa dilakukan penghematan secara lebih intensif. Konsep efisiensi berkaitan dengan seberapa jauh suatu proses mengkonsumsi masukan untuk menghasilkan keluaran tertentu.

\section{Penelitian Terdahulu}

Dermawan (2015) dengan judul penelitian: Analisis Biaya Kualitas Pada PT. Industri Sandang Nusantara Patal Tohpati. Penelitian ini bertujuan untuk mengetahui biaya kualitas pada PT. Industri Sandang Nusantara. Penelitian ini menggunakan metode deskriptif. Hasil penelitian ini adalah Analisis biaya kualitas antara biaya kendali dengan biaya kegagalan tidak seimbang. Adapun persamaan penelitian ini dengan yang dilakukan penulis adalah mengidentifikasi dan menganalisis 
laporan biaya kualitas. Perbedaannya, penulis mencoba menganalisis efisiensi pengendalian terhadap biaya kualitas sedangkan peneliti sebelumnya hanya menganalisis biaya kualitas.

Sandag (2014) dengan judul penelitian: Analisis Biaya Kualitas Dalam Meningkatkan

Profitabilitas Perusahaan Pada CV. Ake Abadi Manado. Penelitian ini bertujuan untuk mengetahui bagaimana perhitungan biaya kualitas perusahaan dalam meningkatkan profitabilitas. Penelitian ini menggunakan metode deskriptif. Hasil penelitian ini adalah biaya kualitas yang terdiri dari biaya pencegahan, biaya penilaian, biaya kegagalan internal dan kegagalan eksternal, memiliki pengaruh secara simultan terhadap profitabilitas perusahaan CV. Ake Abadi Manado. Adapun persamaan penelitian ini dengan yang dilakukan penulis adalah melaporkan besarnya biaya kualitas yang dialokasikan untuk kualitas produk. Perbedaannya penulis mencoba menghitung pengaruh biayabiaya kualitas terhadap efisiensi produksi, sedangkan peneliti sebelumnya hanya mengukur biaya kualitas terhadap profitabilitas perusahaan.

\section{Jenis Penelitian}

\section{METODE PENELITIAN}

Jenis penelitian yang digunakan dalam penelitian ini adalah penelitian deskriptif dengan pendekatan kualitatif. Penelitian deskriptif kualitatif ini bertujuan untuk mendeskripsikan apa-apa yang saat ini berlaku.

\section{Tempat dan Waktu Penelitian}

Untuk memperoleh data yang dibutuhkan dalam penelitian ini, penulis mengadakan penelitian pada Aksan Bakery yang bertempat di Kelurahan Islam Lingkungan 1 Kecamatan Tuminting Kota Manado. Sedangkan jadwal penelitian ini dilaksanakan selama bulan April 2016

\section{Prosedur Penelitian}

1. Menentukan judul dan merumuskan masalah.

2. Mengumpulkan data sesuai permasalahan yang diangkat.

3. Pengumpulan data melalui wawancara terhadap pihak-pihak yang terkait.

4. Mengelola data dan menginterpretasikan hasil pengolahan data.

5. Menarik kesimpulan dan memberikan saran.

\section{Metode Pengumpulan Data}

\section{Jenis Data}

Jenis data yang digunakan penulis dalam penelitian ini adalah data kualitatif yaitu data berbentuk informasi, baik dalam bentuk lisan maupun tulisan yang membantu dan mendukung data yang dibutuhkan misalnya berupa wawancara dengan pimpinan dan karyawan, dan data kuantitatif yaitu data berbentuk angka-angka yang masih perlu dianalisis kembali, misalnya: jumlah biaya kualitas dalam produksi roti pada Aksan Bakery.

2. Sumber Data
a. Data primer
b. Data Sekunder

\section{Teknik Pengumpulan Data}

Untuk memperoleh data yang baik dan tepat dengan asumsi agar sasaran penulisan dapat dicapai, maka penulis menggunakan metode pengumpulan data dengan cara Wawancara atau Interview. Wawancara tersebut didasarkan pada pedoman pertanyaan yang telah disiapkan terlebih dahulu. Dengan harapan wawancara tersebut bisa terarah dan data yang diperlukan dapat terkumpul.

\section{Metode Analisis Data}

Metode yang digunakan untuk menganalisis data adalah metode deskriptif yaitu metode yang digunakan untuk menggambarkan atau menganalisis suatu hasil penelitian tetapi tidak digunakan untuk menggunakan kesimpulan yang lebih luas (Sugiyono 2011:21). Dan metode analisis rasio presentase biaya kualitas, yakni suatu rasio yang membandingkan antara biaya kualitas dengan penjualan. 
Analisis Biaya Kualitas

\section{HASIL PENELITIAN DAN PEMBAHASAN}

Untuk menghasilkan kualitas yang baik, maka perusahaan perlu mengeluarkan sejumlah biaya-biaya untuk mendapatkan kualitas yang baik, serta untuk mengurangi tingkat kerusakan produksi. Melalui pengendalian, suatu perusahaan berusaha memberikan jaminan agar pelaksanaan rencana produksi sesuai dengan yang telah ditetapkan, kemudian melakukan tindakan koreksi atas setiap penyimpangan yang terjadi supaya dapat melakukan perbaikan dimasa datang. Biaya kualitas adalah sejumlah biaya yang dikeluarkan oleh perusahaan, yang meliputi, biaya pencegahan, biaya penilaian, biaya kegagalan internal dan biaya kegagalan eksternal. Penggolongan biayabiaya yang merupakan biaya kualitas pada Aksan Bakery tahun 2015 yaitu sebagai berikut:

1. Biaya Pencegahan (Prevention Cost)

Biaya-biaya yang termasuk biaya pencegahan adalah sebagai berikut:

a. Biaya tenaga kerja pemeliharaan dan perbaikan mesin nerupakan biaya yang dikeluarkan untuk membayar upah tenaga kerja yang berhubungan dengan pemeliharaan dan perbaikan mesin yang menunjang proses produksi. Biaya tenaga kerja untuk pemeliharaan dan perbaikan mesin yaitu sebesar Rp 26.400.000.

b. Yang termasuk dalam biaya pencegahan yang selanjutnya yaitu biaya reparasi atau biaya pemeliharaan mesin yang menunjang proses produksi yang merupakan biaya yang dibebankan untuk pemeliharaan dan perbaikan mesin apabila mengalami kerusakan. Biaya kualitas untuk pemeliharaan dan perbaikan mesin yaitu sebesar $\operatorname{Rp} 24.000 .000$

2. Biaya Penilaian (Appraisal Cost)

Biaya-biaya yang termasuk dalam biaya penilaian ini adalah sebagai berikut:

a. Biaya tenaga kerja pengawas produksi yaitu biaya upah untuk pengawas selama proses produksi berlangsung. Biaya kualitas untuk biaya tenaga kerja pengawas produksi adalah sebesar Rp 34.200.000

b. Biaya pemeriksaan bahan baku dan bahan pembantu yaitu biaya yang dikeluarkan untuk tenaga kerja yang memeriksa bahan baku dan bahan pembantu selama proses produksi. Biaya kualitas untuk biaya pemeriksaan bahan baku dan bahan pembantu yaitu sebesar Rp 30.452.000

3. Biaya kegagalan internal (Internal Failure Costs)

Biaya kualitas yang termasuk dalam biaya kegagalan internal yaitu: Biaya pengerjaan kembali (rework) yaitu biaya yang terjadi karena adanya barang rusak atau belum memenuhi standar yang ditetapkan. Biaya kualitas untuk biaya pengerjaan kembali (rework) yaitu sebesar Rp 75.650 .000

4. Biaya kegagalan eksternal ((External Failure Costs)

Biaya kualitas yang termasuk dalam biaya ini adalah biaya keluhan pelanggan yaitu biaya yang terjadi apabila adanya keluhan pelanggan akibat produk yang tidak sesuai dengan pesanan. Biaya kualitas untuk keluhan pelanggan yaitu sebesar Rp 32.400.00

Laporan Biaya Kualitas Untuk Tahun 2015 adalah sebagai berikut: 
Tabel 1. Laporan Biaya Kualitas Aksan Bakery

\begin{tabular}{|l|c|c|}
\hline \multicolumn{1}{|c|}{ Jenis Biaya } & Jumlah (Rp) & Presentase (\%) \\
\hline A. Biaya Pencegahan & & \\
$\quad$ Biaya tenaga kerja pemeliharaan dan perbaikan & 26.400 .000 & 11,83 \\
$\quad$ Biaya pemeliharaan dan perbaikan & 24.000 .000 & 10,76 \\
Jumlah Biaya Pencegahan & 50.400 .000 & 22,59 \\
B. Biaya Penilaian & 34.200 .000 & 15,33 \\
$\quad$ Biaya tenaga kerja pengawas produksi & 30.452 .000 & 13,65 \\
$\quad$ Biaya pemeriksaan bahan baku dan pembantu & 64.652 .000 & 28,98 \\
Jumlah biaya penilaian & & \\
C. Biaya kegagalan internal & 75.650 .000 & 33,91 \\
$\quad$ Biaya pengerjaan ulang & 75.650 .000 & 33,91 \\
Jumlah biaya kegagalan internal & 32.400 .000 & 14,52 \\
D. Biaya kegagalan eksternal & 32.400 .000 & 14,52 \\
$\quad$ Biaya keluhan pelanggan & $\mathbf{2 2 3 . 1 0 2 . 0 0 0}$ & $\mathbf{1 0 0}$ \\
\hline Jumlah biaya kegagalan eksternal & \multicolumn{2}{|}{} \\
\hline Jumlah biaya kualitas & & \\
\hline
\end{tabular}

Sumber: Data olahan

Setelah proporsi masing-masing golongan biaya kualitas telah diketahui, maka presentasi tersebut dapat dibandingkan berdasarkan peringkatnya, dari golongan biaya kualitas yang terbesar sampai terkecil.

Tabel 4.2 Presentasi Biaya Kualitas berdasarkan peringkat

\begin{tabular}{|lcc|}
\hline \multicolumn{1}{|c|}{ Jenis Biaya } & Jumlah $(\mathbf{R p )}$ & Presentase (\%) \\
\hline Biaya Kegagalan Internal & 75.650 .000 & 33,91 \\
Biaya Penilaian & 64.652 .000 & 28,98 \\
Biaya Pencegahan & 50.400 .000 & 22,59 \\
Biaya Kegagalan Eksternal & 32.400 .000 & 14,52 \\
\hline Total Biaya Kualitas & $\mathbf{2 2 3 . 1 0 2 . 0 0 0}$ & $\mathbf{1 0 0}$ \\
\hline
\end{tabular}

Sumber: Data Olahan

Pada tabel 4.2 terlihat bahwa perbandingan besar biaya kualitas yang terjadi pada Aksan Bakery antara biaya kendali dengan biaya kegagalan tidak seimbang. Proporsi biaya kendali yang terdiri dari biaya pencegahan dan biaya penilaian secara keseluruhan adalah $51,57 \%$ sedangkan proporsi biaya kegagalan yang terdiri dari biaya kegagalan internal dan biaya kegagalan eksternal secara keseluruhan adalah 48,43\%. Pengeluaran biaya kualitas terbesar (lebih dari setengah bagian) berasal dari biaya kendali yaitu biaya pencegahan dan biaya penilaian sebesar 51,57\% .

Menurut hasil wawancara dengan pimpinan perusahaan biaya ini terjadi karena adanya kerusakan terhadap mesin yang digunakan untuk menunjang proses produksi sehingga harus dilakukan perbaikan dan juga pemeliharaan terhadap mesin yang rusak dan juga sering didapati produk yang cacat akibat kelalayan dari pekerja, untuk itu dibutuhkan biaya tenaga kerja pengawas produksi untuk mengawasi jalannya produksi sehingga tidak menyebabkan produk cacat sampai ketangan konsumen. Dapat dilihat bahwa perusahaan sangat memperhatikan hal-hal yang dapat mencegah terjadinya kegagalan produk.

\section{Analisis Efisiensi biaya Kualitas}

Analisis efisiensi biaya kualitas dilakukan dengan membandingkan biaya kualitas terhadap penjualan. Tujuan perbandingan biaya kualitas terhadap penjualan adalah untuk mengetahui apabila biaya kualitas mempunyai presentase yang besar terhadap penjualan maka laba yang seharusnya dapat tercapai oleh perusahaan berkurang. Untuk menganalisis efisiensi biaya kualitas menggunakan rasio presentasi biaya kualitas terhadap penjualan dibutuhkan jumlah anggaran penjualan roti selama tahun 2015 yaitu sebesar $\mathrm{Rp} \mathrm{1.606.400.000.} \mathrm{Setelah} \mathrm{itu} \mathrm{dapat} \mathrm{dilakukan} \mathrm{perhitungan} \mathrm{rasio} \mathrm{anggaran}$ biaya kualitas terhadap penjualan seperti yang digambarkan pada perhitungan dibawah ini: 
Tabel 4.3 Rasio biaya kualitas terhadap penjualan pada Aksan Bakery Tahun 2015

Biaya Kualitas Tahun $2015(\mathrm{Rp})$
Penjualan Tahun 2015(Rp)

(2)
Rasio Biaya Kualitas terhadap Penjualan $(\%)$
(1)

1.606.400.000

$(3)=(1: 2) \times 100 \%$

223.102.000

13,89

Sumber: Data Olahan

Menurut perhitungan rasio presentasi biaya kualitas di peroleh hasil rasio biaya kualitas terhadap penjualan yaitu sebesar $13,89 \%$, yang didapat dari hasil perhitungan biaya kualitas tahun 2015 yaitu sebesar Rp 223.102.000 dibahagi dengan penjualan sebesar Rp 1.606.400.000. Sedangkan, perusahaan dengan pengelolaan kualitas yang baik, biaya kualitasnya tidak lebih dari 2,5\% dari penjualan. Standar 2,5\% diatas mencakup biaya kualitas total. Berikut ini adalah tabel laporan hasil biaya kualitas terhadap penjualan yang dapat dilihat secara lebih rinci:

Tabel 4.4 Laporan Biaya Kualitas Terhadap Penjualan

\begin{tabular}{|c|c|c|c|}
\hline Jenis Biaya & \multicolumn{2}{|c|}{ Biaya Kualitas (Rp) } & $\begin{array}{l}\text { (\%) Terhadap } \\
\text { Penjualan }\end{array}$ \\
\hline \multicolumn{4}{|l|}{ Biaya Pencegahan } \\
\hline $\begin{array}{l}\text { Biaya tenaga kerja pemeliharaan dan } \\
\text { perbaikan }\end{array}$ & 26.400 .000 & & \\
\hline Biaya pemeliharaan dan perbaikan & 24.000 .000 & & \\
\hline $\begin{array}{l}\text { Jumlah Biaya Pencegahan } \\
\text { Biaya Penilaian }\end{array}$ & & 50.400 .000 & 3,14 \\
\hline Biaya tenaga kerja pengawas produksi & 34.200 .000 & & \\
\hline $\begin{array}{l}\text { Biaya pemeriksaan bahan baku dan } \\
\text { pembantu }\end{array}$ & 30.452 .000 & & \\
\hline $\begin{array}{l}\text { Jumlah biaya penilaian } \\
\text { Biaya kegagalan internal }\end{array}$ & & 64.652 .000 & 4,02 \\
\hline Biaya pengerjaan ulang & 75.650 .000 & & \\
\hline $\begin{array}{l}\text { Jumlah biaya kegagalan internal } \\
\text { Biaya kegagalan eksternal }\end{array}$ & & 75.650 .000 & 4,71 \\
\hline Biaya keluhan pelanggan & 32.400 .000 & & \\
\hline Jumlah biaya kegagalan eksternal & & 32.400 .000 & 2,02 \\
\hline Jumlah biaya kualitas & & 223.102.000 & 13,89 \\
\hline Penjualan: & 1.606.400.000 & & \\
\hline
\end{tabular}

Sumber: Data Olahan

Pada tabel 4.4 dapat diketahui bahwa pada tahun 2015 presentasi biaya kualitas adalah 13,89\% dari total penjualan sebesar $\mathrm{Rp}$ 1.606.400.000. Dengan total presentasi terbesar ada pada biaya kendali yaitu $7,16 \%$ dari penjualan sedangkan biaya kegagalan sebasar 6,73\% dari penjualan. Dari hasil analisis sudah dapat dilihat bahwa pengendalian biaya kualitas belum efisien dikarenakan besarnya biaya kualitas yang dikeluarkan tidak sesuai dengan standar biaya kualitas yang telah ditetapkan. Meskipun biaya kendali lebih besar dibandingkan dengan biaya kegagalan namun hal ini belum bisa menekan terjadinya produk cacat sebelum sampai ketangan konsumen. Hal ini dapat dilihat dari besarnya biaya kegagalan internal yaitu biaya pengerjaan kembali. Untuk itu, perlu adanya tambahan biaya pada kategori biaya pencegahan agar dapat menekan biaya kegagalan internal. Terlebih lagi jika penanganan baik dan sungguh-sungguh, tambahan biaya pencegahan akan lebih kecil 
dari pengurangan biaya kegagalan internal, sehingga secara keseluruhan total biaya kualitas akan berkurang.

Untuk itu Aksan Bakery masih membutuhkan upaya-upaya perbaikan untuk mencapai sasaran biaya kualitas sebesar $2,5 \%$ dari total penjualan. Perusahaan harus menentukan tingkat kualitas optimal dan menetapkan jumlah relatif yang digunakan disetiap kategori. Pada saat perusahaan semakin banyak membelanjakan pada aktivitas pencegahan dan penilaian, maka presentasi unit cacat menjadi rendah. Hal ini menyebabkan biaya kegagalan internal dan biaya kegagalan eksternal menjadi lebih rendah.

\section{Kesimpulan}

\section{PENUTUP}

Berdasarkan hasil penelitian maka dapat diambil kesimpulan bahwa pengendalian biaya kualitas pada Aksan Bakery belum dilakukan secara efisien karena biaya kualitas yang efisien adalah 2,5\% terhadap penjualan sedangkan biaya kualitas yang dikeluarkan oleh Aksan Bakery adalah $13,89 \%$ dari total penjualan sebesar Rp 1.606.400.000 yang terdiri dari 3,14\% biaya pencegahan, 4,02\% biaya penilaian, $4,71 \%$ biaya kegagalan internal dan 2,02\% biaya kegagalan eksternal. Meskipun biaya kendali lebih besar dibandingkan dengan biaya kegagalan namun ini belum bisa menekan terjadinya produk cacat sebelum sampai ketangan konsumen yang dilihat dari besarnya biaya kegagalan eksternal. Hal ini didasarkan pada biaya-biaya yang berkaitan dengan kualitas sudah dikeluarkan oleh perusahaan tetapi perusahaan belum mengidentifikasi, mengelompokkan dan melaporkan biaya kualitas secara terpisah. Biaya tersebut masih tergabung dengan laporan biaya produksi. Sehingga biaya kualitas tidak dapat terkontrol oleh perusaahaan. Adapun biaya-biaya yang dikeluarkan oleh Aksan Bakery dikelompokkan menjadi 4 golongan. Biaya Pencegahan yang meliputi: Biaya tenaga kerja pemeliharaan dan perbaikan mesin serta Biaya pemeliharaan dan perbaikan mesin. Biaya Penilaian yang meliputi: Biaya tenaga kerja pengawas produksi dan biaya pemeriksaan bahan baku. Biaya Kegagalan yang meliputi Biaya pengerjaan ulang dan Biaya Kegagalan Eksternal yang meliputi biaya keluhan pelanggan.

\section{Saran}

1. Aksan Bakery hendaknya mengidentifikasi dan melaporkan biaya kualitas secara terpisah karena biaya kualitas masih tergabung dengan laporan biaya produksi. Hal ini dimaksudkan agar dapat mengetahui biaya kualitas yang telah dikeluarkan oleh perusahaan sehingga dapat dilakukan pengendalian biaya kualitas secara lebih baik agar tercipta efisiensi biaya kualitas.

2. Diharapkan perusahaan lebih meningkatkan aktivitas pencegahan sebagai upaya peningkatan dan pengendalian terhadap kualitas produk agar dapat mencapai tingkat kerusakan nol sehingga tidak ada biaya kegagalan yang harus ditanggung oleh perusahaan.

3. Perusahaan sebaiknya meningkatkan training secara berkelanjutan agar karyawan dapat melakukan proses produksi secara benar serta menekan tingkat kecacatan suatu produk akibat faktor manusia, serta mengadakan pemeliharaan mesin secara berkala dan terjadwal.

\section{DAFTAR PUSTAKA}

Buchori, M. Khuwarismi. 2012. Analisis Hubungan Biaya Kualitas Dengan Kecacatan Produk PT. Sport Glove Indonesia, diakses dari http://digilib.uin-suka.ac.id/id/eprint/8096 pada tanggal 8 April 2016.

Darsono Prawinegoro, Ari Purwanti. 2013. Akuntansi Manajemen, edisi 3 revisi. Jakarta: Mitra Wacana Media.

Darmawan. 2015. Analisis Biaya Kualitas Pada PT. Industri Sandang Nusantara Patal Tohpati. Universitas Pendidikan Genesha. Ejournal, diakses dari http://ejournal.undiksha.ac.id/index.php/JJPE/article/viewFile/5254/3984 pada tanggal 10 April 2016

Fahmi, I. 2012. Manajemen Produksi dan Operasi. Edisi 1. ALFABETA. BANDUNG.

Firdaus Ahmad., Wasilah Abdullah. 2012. Akuntansi Biaya Edisi Ketiga. Salemba Empat. Jakarta.

Garrison, Noreen, dan Brewer. 2013, Akuntansi Manajerial, Salemba Empat, Jakarta. 
Garrison, Ray H., Noreen Eric W., Brewer, Peter C. 2012. Managerial Acconting. New York: The McGraw-Hill Companies.

Krismiaji., Aryani Anni. 2011. Akuntansi Manajemen. Edisi Kedua. UPP STIE YKPN. Yogyakarta

Kusumawati, Rika, 2014, Manfaat Biaya Kualitas Dalam Upaya Peningkatan Produktifitas Perusahaan. Sekolah Tinggi Ilmu Ekonomi Indonesia. Jurnal Ilmu dan Riset Akuntansi. Di akses pada tanggal 7 April 2016 dari http://ejournal.stiesia.ac.id/index.php/jira/issue/view/19/showToc

Mulyadi. 2012. Akuntansi Biaya. Edisi Kelima, Penerbit UPP STIE, Yogyakarta.

Nasution, M, N, 2001, Manajemen Mutu Terpadu (Total Quality Management), Cetakan Pertama, Penerbit : Ghalia Indonesia, Jakarta.

Sandag E. Nefriani. 2014. Analisis Biaya Kualitas Dalam Meningkatkan Profitabilitas Perusahaan Pada CV. Ake Abadi Manado. Jurnal EMBA. ISSN: 2303-1174. Vol 2. No 2 (2014). diakses dari http://ejournal.unsrat.ac.id/index.php/emba/article/view/4721 diakses pada tanggal 11 April 2016.

Sugiyono, 2011. Metode Penelitian Kualitatif dan R\&D. Penerbit Alfabeta, Bandung. 